\title{
Ascomycetes from freshwater habitats: Ascolacicola aquatica gen. et sp. nov. and a new species of Ascotaiwania from wood submerged in a reservoir in Hong Kong
}

\author{
V. Mala Ranghoo \\ Kevin D. Hyde \\ Department of Ecology and Biodiversity, The University \\ of Hong Kong, Pokfulam Road, Hong Kong
}

\begin{abstract}
Ascolacicola aquatica gen. et sp. nov., and Ascotaiwania mitriformis sp. nov., from decaying submerged wood collected in the Plover Cove Reservoir in Hong Kong are described and illustrated. Ascolacicola aquatica has characteristics that are common to both Ascotaiwania and Savoryella, but the anamorph is Trichocladium uniseptatum. A new genus is therefore introduced to accommodate this fungus. Ascotaiwania mitriformis sp. nov. is typical of the genus and differs from other species in having large brown fusiform ascospores with mitriform end cells. Its anamorph is an undescribed species of Monotosporella and both states of the fungus are described and illustrated.
\end{abstract}

Key Words: Ascomycetes, anamorph, lignicolous fungi, Sordariales, systematics

\section{INTRODUCTION}

During examination of freshwater fungi occurring on submerged wood in the Plover Cove Reservoir, The New Territories, Hong Kong, we identified two new species of ascomycetes with brown, septate ascospores which had paler end cells. Both fungi resemble species of Ascotaiwania Sivan. \& H. S. Chang. However in pure cultures obtained from single ascospores, one fungus produced a Trichocladium uniseptatum Berk. \& Broome anamorph, while the other produced a Monotosporella S. Hughes, anamorph. Monotosporella has previously been shown to be the anamorph of Ascotaiwania sawada H. S. Chang \& Y. S. Hsieh (Sivichai et al., 1998). This latter species with large brown fusiform ascospores and hyaline mitriform end cells conforms to Ascotaiwania, and is therefore described as a new species, $A$. mitriformis. The other species has several characters atypical for Ascotaiwania; including ascomata with relatively short necks, filamentous, persistent paraphyses, asci with discoid refractive apical

Accepted for publication May 28, 1998.

' Email: ranghoo@hkusua.hku.hk rings, relatively small ellipsoidal ascospores and a Trichocladium anamorph. We therefore introduce a new genus to accommodate it.

\section{MATERIALS AND METHODS}

Submerged wood was collected from the Plover Cove Reservoir and returned to the laboratory in sterile plastic bags. Samples were incubated in moist plastic boxes at room temperature and examined periodically over 2-3 mo. Squash mounts of ascomata in water were made for microscopic examination. Measurements of ascomata were made from thin sections or whole mounts in water. The contents of the ascomata were removed from the ascomata and a spore suspension was made with sterile distilled water in a watch-glass and the suspension was pipetted onto potato dextrose agar (PDA). The single ascospores were allowed to germinate ( $\mathrm{ca} 2 \mathrm{~d}$ ) and then they were transferred to smaller PDA plates for further growth.

\section{DESCRIPTION}

Ascolacicola Ranghoo et K. D. Hyde, gen. nov.

Ascomata superficialia, subglobosa, nigra, ostiolata, papillata, paraphysata, solitaria vel gregaria. Asci octospori, cylindrici, breviter pedicellati, unitunicati, J- apparato apicale praediti. Ascosporae uniseriatae, ellipsoideae, hyalinae, 4 cellulatae, cellulis centralibus brunneis, cellulis polaribus hyalinis vel pallide brunneis. Status anamorphosis: Trichocladium uniseptatum.

Ascomata superficial, subglobose, black, coriaceous, solitary to gregarious and beaked. Peridium comprising several layers of brown flattened angular cells. Paraphyses filamentous, hyaline, numerous, flexuous, septate, rounded at the ends. Asci 8-spored, cylindrical, short pedicellate, unitunicate, apically rounded, with a J-, refractive, discoid, apical ring. Ascospores overlapping uniseriate, ellipsoidal, 4-celled, not constricted at the septa, brown with hyaline to pale brown end cells, smooth walled. Anamorph: Trichocladium uniseptatum.

Etymology. From the Latin lacus meaning "reservoir" and cola meaning "dwelling."

Species typica. Ascolacicola aquatica Ranghoo et K. D. Hyde. 
Ascolacicola aquatica Ranghoo et K. D. Hyde, sp. nov. FIGS. 1-11

Ascomata 250-375 $\mu \mathrm{m}$ alta, 225-275 $\mu \mathrm{m}$ diam, superficialia, subglobosa, nigra, ostiolata, papillata, paraphysata, solitaria vel gregaria. Peridium 18-27.5 $\mu \mathrm{m}$ crassum. Asci 125-163 × 10-12.5 $\mu \mathrm{m}, 8$-spori, cylindrici, breviter pedicellati, apparato apicale 3.75 alto, $6.25 \mu \mathrm{m}$ diam, praediti. Ascosporae 12.5-16.5 $\times$ 4-7.5 $\mu \mathrm{m}$, uniseriatae imbricatae, ellipsoideae, 4-cellulatae, cellulis centralibus brunneis, cellulis polaribus hyalinis vel pallide brunneis.

Ascomata 250-375 $\mu \mathrm{m}$ high, 225-275 $\mu \mathrm{m}$ diam, superficial, subglobose, black, coriaceous, solitary to gregarious. Neck 175-200 $\mu \mathrm{m}$ high, 62.5-75 $\mu \mathrm{m}$ diam (FIGS. 1, 2), periphysate, beaked, black. Peridium 18-27.5 $\mu \mathrm{m}$ wide, comprising of 5-7 layers of brown flattened angular cells (FIG. 3). Paraphyses 175-200 × 2.5-3.8 $\mu \mathrm{m}$, filamentous, hyaline, numerous, septate, apically rounded (FIG. 7). Asci 125-163 $\times 10-12.5 \mu \mathrm{m}, 8$-spored, cylindrical, short pedicellate, apically rounded, with a J-, refractive, discoid, apical ring, 2.5-3.7 $\mu \mathrm{m}$ high, $6.2 \mu \mathrm{m}$ diam (FIGS. 46,8 ). Ascospores 12.5-16.5 $\times 4-7.5 \mu \mathrm{m}$ (mean $=$ $15.9 \times 5.6 \mu \mathrm{m}, \mathrm{n}=50)$, uniseriate, ellipsoidal, 4celled, not constricted at the septa, brown with hyaline to pale brown end cells, smooth walled (FIGS. 9$11)$.

HOLOTYPE. HONG KONG. THE NEW TERRITORIES: The Plover Cove Reservoir, on submerged wood, March 1997, V. M. Ranghoo (HKU(M) 5243).

Additional material examined. HONG KONG. THE NEW TERRITORIES: Lam Tsuen River, Tai Po, on submerged wood, July 1997, K. M. Tsui (HKU(M)5542).

Etymology. In reference to the freshwater habitat where the species was collected.

Habitat. Saprobic on submerged wood.

Known distribution. Hong Kong.

Description of anamorph. Colonies on PDA reaching $1 \mathrm{~cm}$ diam after 1 mo incubation at room temperature $(25 \mathrm{C})$, with dark gray cottony mycelium, producing gray aerial mycelium on the surface, growing mainly in concentric rings. Black pigment diffusing into the agar, anamorph produced in culture.

Trichocladium uniseptatum Berk. \& Broome (Hughes and Pirozynski, 1972)

FIGS. 12-21

Vegetative hyphae partly superficial and partly immersed, branched and septate, not constricted at the septa, hyaline, 1-3 $\mu \mathrm{m}$ wide (FIGS. 12-14). Conidiogenous cells thin-walled, hyaline, sometimes thickened and pigmented near the base, subglobose, ampulliform, or irregularly cylindrical, $5-7 \times 5-8 \mu \mathrm{m}$ (mean $=6 \times 7 \mu \mathrm{m}, \mathrm{n}=50$ ), bearing a single terminal conidium (Figs. 15, 16, 18, 19). Chlamydo- spores produced in culture (FIG. 17). Conidia broadly obovoid, 1-septate near the base, slightly constricted at the septa when mature, 3.8-6.3 $\times 6.5-10 \mu \mathrm{m}$ (mean $=5 \times 7.5 \mu \mathrm{m}, \mathrm{n}=50$ ) with the upper cell rounded, thick-walled, dark-brown (FIGS. 20, 21).

Discussion. Ascotaiwania and Savoryella E. B. G. Jones \& R. A. Eaton are freshwater ascomycete genera with unitunicate asci producing brown ascospores with hyaline end cells. Four other terrestrial genera of unitunicate ascomycetes producing the same type of ascospores are Ascocodinaea Samuels, Botanamphora Nograsek \& Scheuer, Melanamphora Lafl., and Melanochaeta E. Müll., Harr \& Sulmont. These genera can easily be separated from Ascolacicola using several important morphological characters, including the presence or absence of particular anamorphs, and these are shown in TABLE I.

Ascolacicola aquatica has some characters that are typical of Ascotaiwania; namely immersed ascomata; a peridium of brown walled flattened cells; cylindrical asci; and brown septate ascospores with hyaline end cells. Ascolacicola aquatica, however, differs in having ascomata with shorter necks, asci with discoid apical rings which are relatively flattened as compared to the large bipartite refractive apical rings typical of the genus Ascotaiwania (Sivanesan and Chang, 1992; Chang et al., 1998). The large refractive apical ring in the type species of Ascotaiwania, A. lignicola described by Sivanesan and Chang (1992) was one of the characteristics which distinguished it from other related genera and the taxonomic placement of $A s$ cotaiwania at the family level was also based on this morphological character. Later studies carried out on the large bipartite ring at the ultrastructural level as described by Chang et al. (1998) gave evidence for the transfer of Ascotaiwania to the Annulatascacae, a family comprising genera with similar apical rings and ascospore morphology (Wong et al., 1998). The flattened apical ring of Ascolacicola is typical of the Sordariales (Barr, 1990) but distinctly different from that of Ascotaiwania and until now ascal apical ring structure variability has not been considered as a variable morphological character of the genus Ascotaiwania (Chang et al., 1998). Moreover, the ascospores in A. aquatica are relatively small, lighter in color and have rounded end cells. The paraphyses in A. aquatica are also thin, filamentous, being numerous and persistent, as compared to the sparse and early deliquescing paraphyses which are typical of Ascotaiwania (Sivanesan and Chang, 1992; Chang et al., 1998). Until now only 2 species of Ascotaiwania have been reported to produce the Monotosporella anamorph in culture (Sivichai et al., 1998) and the anamorph Trichocladium uniseptatum produced in culture of Asco- 


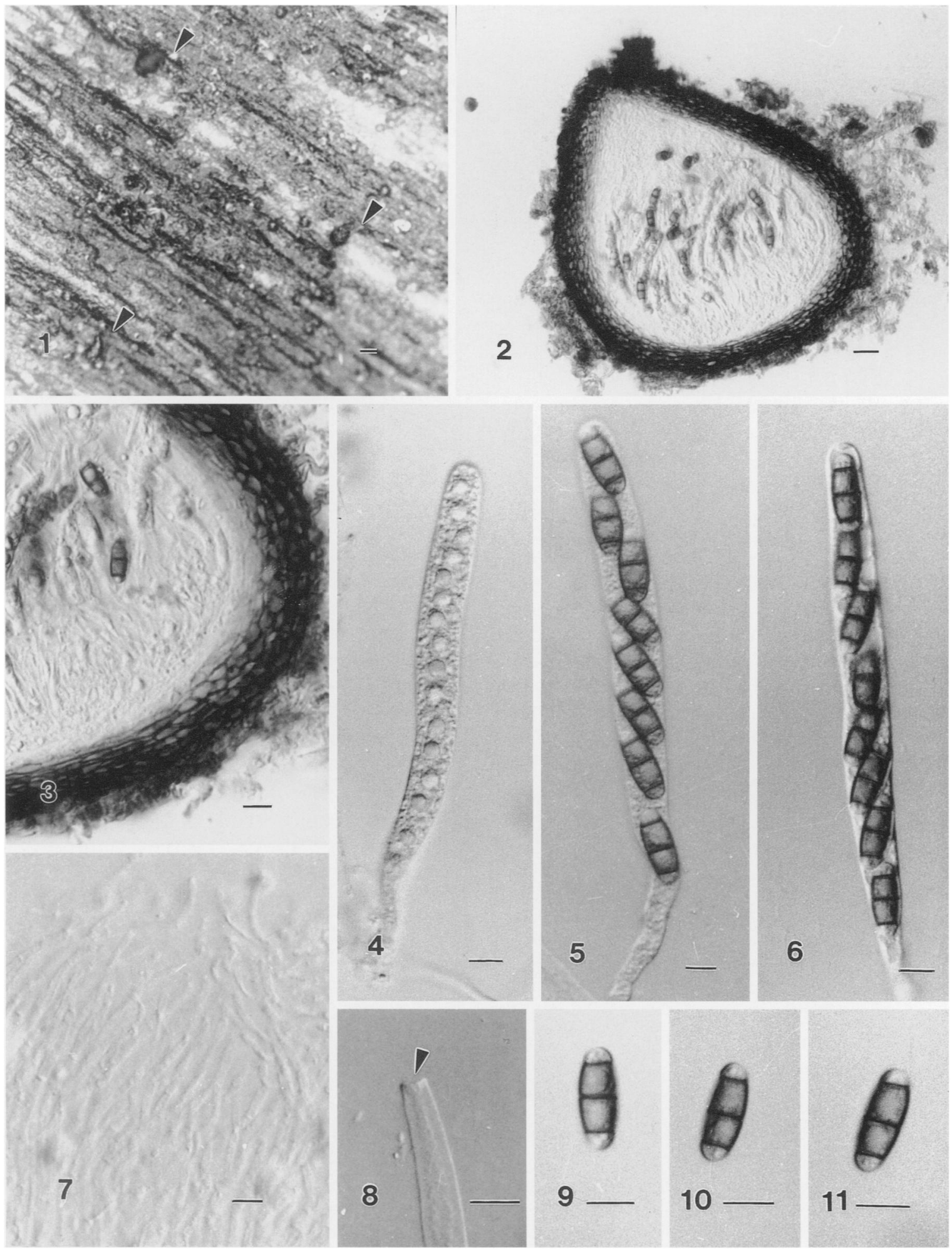

Figs. 1-11. Ascolacicola aquatica (from HKU(M) 5243). 1. Ascomata on wood (arrowed). 2. Section through ascoma. 3. Peridium consisting of 5-7 layers of brown flattened angular cells. 4. Ascus with immature hyaline ascospores. 5, 6. Mature asci with brown ascospores. 7. Numerous thin, filamentous paraphyses. 8. Ascal apical ring (arrowed) which is discoid. 9-11. Ascospores with rounded end cells. Scale bars: $1=200 \mu \mathrm{m}, 2=20 \mu \mathrm{m}, 3,4=10 \mu \mathrm{m}, 5-7=100 \mu \mathrm{m}, 8-11=10 \mu \mathrm{m}$. 


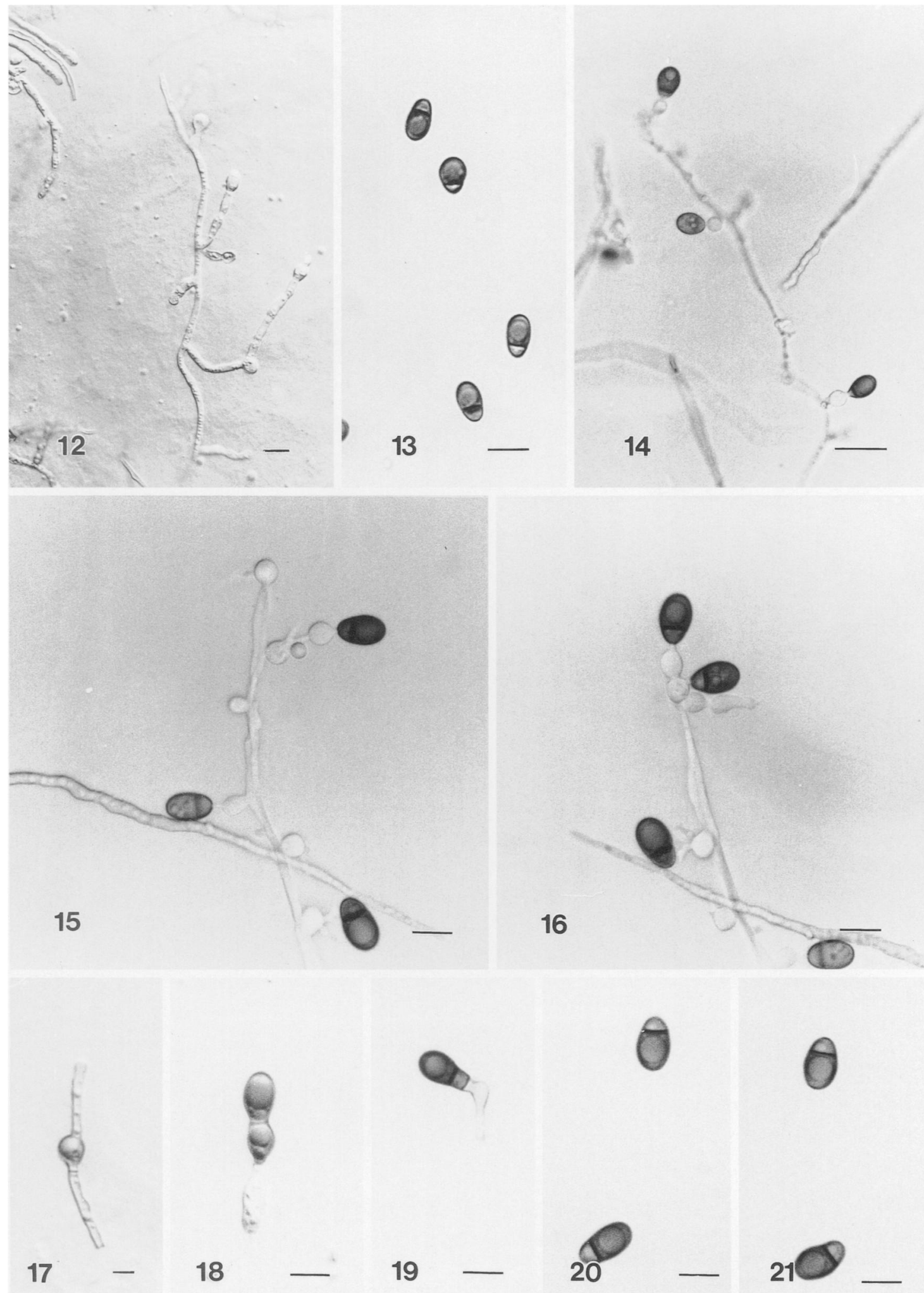

FIGS. 12-21. Trichocladium uniseptatum. 12. Developing conidia. 13. Conidia. 14-16. Mature conidia with attached conidiogenous cells. 17. Chlamydospore produced in culture. 18. Conidium produced in chains. 19. Conidium attached to conidiogenous cell. 20,21 . Fully developed conidia. Scale bars: $12-14=10 \mu \mathrm{m}, 15-21=5 \mu \mathrm{m}$. 
TABLE I. A synopsis of the genera of unitunicate ascomycetes which produce brown ascospores with hyaline end cells

\begin{tabular}{|c|c|c|c|c|c|}
\hline Genus & Ascomatal characters & $\begin{array}{l}\text { Ascus apical } \\
\text { ring }\end{array}$ & $\begin{array}{c}\text { No. of } \\
\text { septa in } \\
\text { ascospore }\end{array}$ & Anamorph & Family \\
\hline Ascocodinaea & $\begin{array}{l}\text { Presence of sterile hy- } \\
\text { phae, no stroma }\end{array}$ & $\mathrm{J}-$, discoid & 3 & Codinaea & Lasiosphaeriaceae \\
\hline Ascolacicola & $\begin{array}{l}\text { Beaked, no stroma } \\
\text { present and small } \\
\text { neck }\end{array}$ & $\begin{array}{l}\mathrm{J}-, \begin{array}{l}2-3.5 \times 5-6 \mu \mathrm{m} \\
\text { discoid }\end{array}\end{array}$ & 3 & Trichocladium & Lasiosphaeriaceae \\
\hline Ascotaiwania & $\begin{array}{l}\text { No stroma, long and } \\
\text { periphysate neck }\end{array}$ & $\begin{array}{l}\mathrm{J}-, \quad 5-7 \times 6-10 \mu \mathrm{m}, \\
\text { bipartite }\end{array}$ & $3-7$ & Monotosporella & Annulatascaceae \\
\hline Botanamphora & $\begin{array}{l}\text { Reduced stroma pres- } \\
\text { ent }\end{array}$ & $\mathrm{J}+$, thin, discoid & 5 & Unknown & Melanconidaceae \\
\hline Melanamphora & $\begin{array}{l}\text { Well developed stroma } \\
\text { present }\end{array}$ & $\begin{array}{l}\mathrm{J}+, 3 \times 5-6 \mu \mathrm{m}, \\
\quad \text { discoid }\end{array}$ & 7 & Cytosporina & Melanconidaceae \\
\hline Melanochaeta & Basal stroma present & $\mathrm{J}+$, thin, discoid & $3-5$ & Sporoschisma & Lasiosphaeriaceae \\
\hline Savoryella & $\begin{array}{l}\text { No stroma, relatively } \\
\text { long periphysate } \\
\text { neck }\end{array}$ & $\begin{array}{c}\mathrm{J}-, 1.5-2 \times 4-5 \\
\mu \mathrm{m}, \text { discoid }\end{array}$ & 3 & Unknown & Lasiosphaeriaceae \\
\hline
\end{tabular}

lacicola leaves no doubt in our minds that Ascolacicola and Ascotaiwania are distinct genera.

Ascolacicola aquatica shares some features with the genus Savoryella; namely the discoid apical ring and the similar shape of the 3-septate ascospores (Ho et al., 1997). The ascospore end cells in A. aquatica, however, are hyaline to pale brown, and differ in shape from those found in species of Savoryella, which are hyaline, comparatively smaller and are more constricted at the septa. The paraphyses in the genus Savoryella are also sparse, while in A. aquatica they are numerous, flexuous and filamentous.

Ascolacicola aquatica differs from species of Botanamphora in having generally smaller ascomata which are not embedded in a stroma, smaller asci, and ascospores which are 5-septate and more elongate. It also differs from species of Melanamphora in having ascomata which are not embedded in any type of stromatic tissue. Melanamphora species also have ascospores which are 5- and 7-septate, larger, curved and cylindrical in shape, and asci which are considerably larger. Melanamphora species also differ from Ascolacicola in that they produce a Cytosporina Sacc. anamorph.

Ascolacicola aquatica also resembles Melanochaeta in having multiseptate brown ascospores with hyaline end cells. However, the absence of setae or hair like structures on the ascomata, the shape of the ascospores and the absence of a Sporoschisma Berk. \& Broome anamorph eliminates $A$. aquatica from the genus (Goh et al., 1997).

Ascolacicola aquatica can also be compared with Ascocodinaea Samuels. Ascolacicola resembles Ascocodinaea in having 3-septate brown ascospores, but differs in lacking setae on the ascomata. The Codinaea Maire anamorph also eliminates Ascolacicola from the genus (Samuels et al., 1997).

Ascolacicola is best placed in the Lasiosphaeriaceae, Sordariales (sensu Barr, 1990) due to the presence of a combination of morphological characters typical of the family. These include dark, membranous ascomata, long cylindrical asci having apical rings, and a centrum interspersed with paraphyses (Barr, 1990).

\section{Ascotaiwania mitriformis Ranghoo et K. D. Hyde, sp. nov. \\ FIGS. 22-30}

Ascomata 400-450 $\mu \mathrm{m}$ alta, 500-560 $\mu \mathrm{m}$ diam, semi-immersa, subglobosa, nigra, ostiolata, papillata, paraphysata, solitaria vel gregaria. Asci 325-375 × 25-35 $\mu \mathrm{m}$, octospori, cylindrici, breviter pedicellati, unitunicati, apparato apicale 7.5-10.0 $\mu \mathrm{m}$ alto, 12.5-15.0 $\mu \mathrm{m}$ diam, praediti. Ascosporae $62.5-72.5 \times 12.5-17.5 \mu \mathrm{m}($ mean $=66.4 \times 15.1 \mu \mathrm{m}, \mathrm{n}=$ 25), uniseriatae imbricatae, ellipsoideae, 7-septatae, cellulis centralibus brunneis, cellulis polaribus hyalinis vel pallide brunneis.

Ascomata 400-450 $\mu \mathrm{m}$ high, 500-560 $\mu \mathrm{m}$ diam, semi-immersed, subglobose, black, coriaceous, solitary to gregarious (FIG. 22). Neck 450-500 $\mu \mathrm{m}$ high, 125-150 $\mu \mathrm{m}$ diam, black, periphysate. Peridium 20$45 \mu \mathrm{m}$, composed of 5-7 layers of brown angular cells. Paraphyses 250-325 × 3.8-5 $\mu \mathrm{m}$, hypha like, septate, branched and tapering towards the apex (FIG. 26). Asci 325-375 × 25-35 $\mu \mathrm{m}$, 8-spored, cylindrical, short pedicellate, apically rounded with a relatively massive, J- apical ring, 7.5-10 $\mu \mathrm{m}$ high, 12.5$15 \mu \mathrm{m}$ wide (FIGS. 23-25). Ascospores 62.5-72.5 $\times$ 12.5-17.5 $\mu \mathrm{m}($ mean $=66.4 \times 15.1 \mu \mathrm{m}, \mathrm{n}=25)$, 


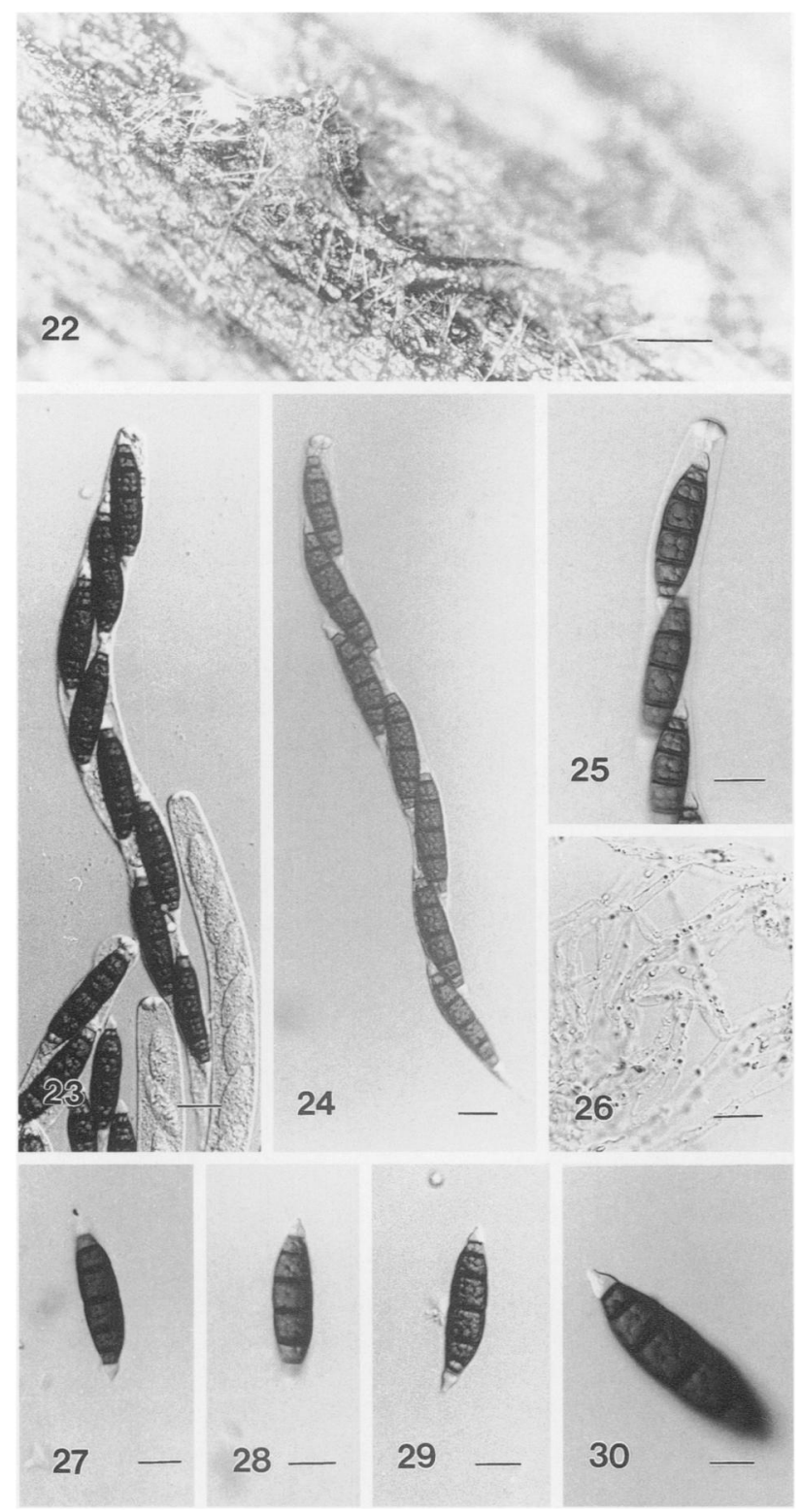

FIGS. 22-30. Ascotaiwania mitriformis (from HKU(M) 5224). 22. Superficial ascoma on wood. 23, 24. Mature asci. 25. Apical ring of ascus. 26. Deliquescing paraphyses. 2729. Ascospores. 30. Close-up of an ascospore illustrating the mitriform end cell. Scale bars: $22=100 \mu \mathrm{m}, 23-30=20$ $\mu \mathrm{m}$.

overlapping uniseriate, fusiform, 7-septate, not constricted at the septa, brown with hyaline end cells which are mitriform in shape, smooth-walled (FIGS. 27-30).

HOLOTYPE. HONG KONG. THE NEW TERRITORIES: The Plover Cove Reservoir, on submerged wood, 26 Jan. 1997, V. M. Ranghoo (HKU(M) 5224).

Etymology. From the Latin, mitriformis in reference to the mitriform end cells of the ascospores.

Habitat. Saprobic on submerged wood.
Known distribution. Hong Kong.

Description of anamorph. Colonies on PDA immersed, reaching $1 \mathrm{~cm}$ diam after $1 \mathrm{mo}$ at room temperature $(25 \mathrm{C})$, with a dense mass of gray cottony aerial hyphae, with immersed hyphae grayish black and gray aerial hyphae, growing in concentric rings. Hyphae causing a black pigmentation in the surrounding medium.

\section{Monotosporella state of Ascotaiwania mitriformis}

Figs. 31-34

Conidiophores erect, pale brown to brown, unbranched, 1- to 3-septate, 25-75 $\times$ 6.25-8.75 $\mu \mathrm{m}$ (mean $=50 \times 7.5 \mu \mathrm{m}, \mathrm{n}=25)$, with 2-4 percurrent proliferations (FIGS. 31, 32). Conidiogenous cells erect, dark brown to black, septate, smooth and thick walled. Conidia 10-20 $\times$ 30-35 $\mu \mathrm{m}$ (mean $=15 \times$ $32.5 \mu \mathrm{m}, \mathrm{n}=25$ ), obovate to oval, solitary, dry, smooth, thick walled, 1-3 septate, basal cell darkbrown, upper cell black, slightly constricted at the septa (FIGS. 31-34).

Discussion. Sivanesan and Chang (1992) established the genus Ascotaiwania for the type species $A$. lignicola Sivan. \& H. S. Chang, an aquatic ascomycete with 7-septate brown ascospores with hyaline end cells. A second species, A. palmicola K. D. Hyde, was described for an ascomycete with 3-septate ascospores from palms. Chang et al. (1998) also described 3 additional species in the genus, namely $A$. hsilio H. S. Chang \& Y. S. Hsieh, A. sawada H. S. Chang \& Y. S. Hsieh, A. wulai H. S. Chang \& Y. S. Hsieh.

Ascotaiwania mitrifomis is very similar to $A$. lignicola and $A$. wulai in having 7-septate ascospores with hyaline end cells and a relatively massive refractive apical ring and we are confident of its inclusion in Ascotaiwania. The ascospores in A. mitriformis, however, are the largest in the genus, as compared to those in A. lignicola $(42-55 \times 8-13 \mu \mathrm{m})$ and $A$. wulai (53-62 $\times 14-16 \mu \mathrm{m})$. The ascospore end cells in $A$. mitriformis are also mitriform in shape, while in the other species they are truncate. A synopsis of the characters of the species of Ascotaiwania is given in TABLE. II.

Sivichai et al. (1998) have recently reported a species of Monotosporella in single spore isolations of $A$. sawada. The Monotosporella species reported in the culture of Ascotaiwania mitriformis differs from the anamorph of $A$. sawada and also differs from the other described species of Monotosporella.

\section{KEY TO ASCOTAIWANIA SPECIES}

1. Ascospores 7-septate, longer than $50 \mu \mathrm{m} \ldots \ldots \ldots 4$

1. Ascospores with fewer than 7 septa, less than $50 \mu \mathrm{m}$

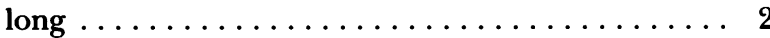




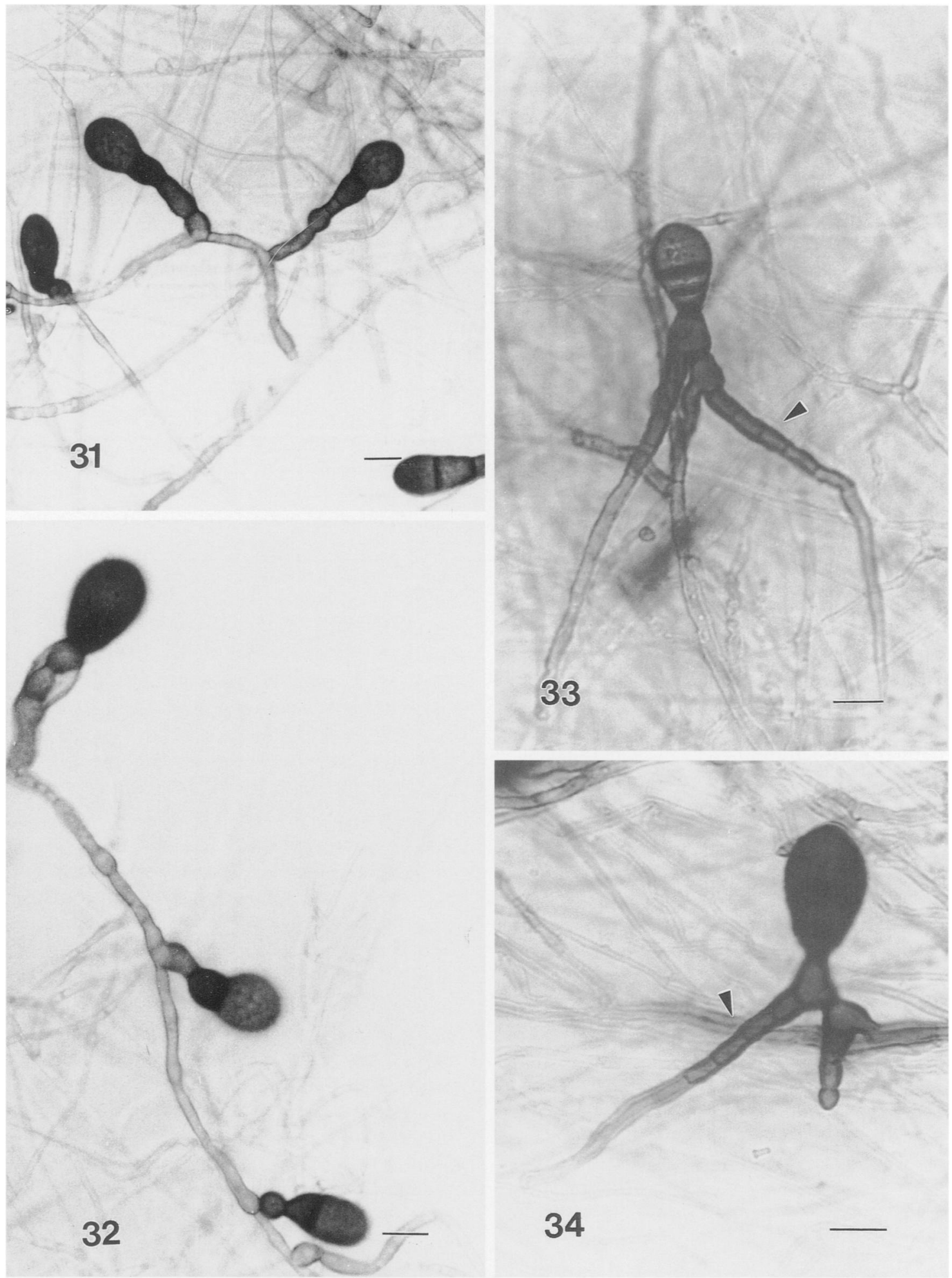

FIGs. 31-34. Monotosporella state of Ascotaiwania mitriformis in culture. 31, 32. Immature conidia growing in series along the mycelium. 33, 34. Mature conidia with conidiophores proliferating percurrently (arrowed). Note the rhizomorphs. Scale bars: $10 \mu \mathrm{m}$. 
TABLE II. A synopsis of the characteristics of species of Ascotaiwania

\begin{tabular}{|c|c|c|c|c|c|c|}
\hline & $\begin{array}{l}\text { A. palmicola } \\
\text { (Hyde, 1995) }\end{array}$ & $\begin{array}{c}\text { A. sawada } \\
\text { (Chang } \\
\text { et al. 1998) }\end{array}$ & $\begin{array}{c}\text { A. hsilio } \\
\text { (Chang } \\
\text { et al. 1998) }\end{array}$ & A. mitriformis & $\begin{array}{l}\text { A. lignicola } \\
\text { (Sivanesan } \\
\text { and } \\
\text { Chang, 1992) }\end{array}$ & $\begin{array}{c}\text { A. wulai } \\
\text { (Chang } \\
\text { et al. 1998) }\end{array}$ \\
\hline Ascomata & $\begin{array}{l}200-250 \times \\
210-350 \mu \mathrm{m} \\
\text { Immersed }\end{array}$ & $\begin{array}{l}242-278 \times \\
541-564 \mu \mathrm{m} \\
\text { Partly to ful- } \\
\text { ly immersed }\end{array}$ & $\begin{array}{l}205-273 \times \\
307-410 \mu \mathrm{m} \\
\text { Partly to ful- } \\
\text { ly immersed }\end{array}$ & $\begin{array}{l}400-450 \times 500- \\
560 \mu \mathrm{m} \text { Semi- } \\
\text { immersed }\end{array}$ & $\begin{array}{l}300-600 \times \\
190-230 \mu \mathrm{m} \\
\text { Partly to ful- } \\
\text { ly immersed }\end{array}$ & $\begin{array}{l}480-744 \times \\
297-518 \mu \mathrm{m} \\
\text { Partly to ful- } \\
\text { ly immersed }\end{array}$ \\
\hline Asci & $\begin{array}{l}150-175 \times \\
7.5-8 \mu \mathrm{m}\end{array}$ & $\begin{array}{l}180-187 \times \\
13.3-15.5 \\
\mu \mathrm{m}\end{array}$ & $\begin{array}{l}120-140 \times \\
12.3-13.4 \\
\mu \mathrm{m}\end{array}$ & $\begin{array}{l}325-375 \times 25-35 \\
\quad \mu \mathrm{m}\end{array}$ & $\begin{array}{l}234-290 \times 13- \\
19 \mu \mathrm{m}\end{array}$ & $\begin{array}{l}274-308 \times 17- \\
\quad 21 \mu \mathrm{m}\end{array}$ \\
\hline Aprical ring & $5 \times 4 \mu \mathrm{m}$ & $\begin{array}{l}4.8-5.1 \times 7.1- \\
10.3 \mu \mathrm{m}\end{array}$ & $\begin{array}{l}3.8-4.5 \times 5.8- \\
\quad 7.2 \mu \mathrm{m}\end{array}$ & $\begin{array}{l}7.5-10 \times 12.5-15 \\
\mu \mathrm{m}\end{array}$ & $\begin{array}{c}7-9.2 \times 5.3- \\
6.7 \mu \mathrm{m}\end{array}$ & $\begin{array}{l}7.5-9.7 \times \\
11.4-13 \mu \mathrm{m}\end{array}$ \\
\hline Ascospores & $\begin{array}{c}\text { 3-septate } \\
17.5-20 \times \\
5-6.5 \mu \mathrm{m}\end{array}$ & $\begin{array}{l}\text { 3-septate } \\
25.4-44.6 \times \\
7.1-10.3 \mu \mathrm{m}\end{array}$ & $\begin{array}{l}\text { 5-septate } \\
\quad 25.3-29 \times \\
7.1-7.7 \mu \mathrm{m}\end{array}$ & $\begin{array}{l}\text { 7-septate } \\
\quad 62.5-72.5 \times \\
12.5-17.5 \mu \mathrm{m}\end{array}$ & $\begin{array}{l}\text { 7-septate } \\
\quad 42-55 \times 8- \\
13 \mu \mathrm{m}\end{array}$ & $\begin{array}{l}\text { 7-septate } \\
\quad 53-62 \times 14- \\
16 \mu \mathrm{m}\end{array}$ \\
\hline $\begin{array}{l}\text { Shape of end } \\
\text { cells }\end{array}$ & Rounded & Rounded & Rounded & Mitriform & Rounded & Rounded \\
\hline Habitat & Palm & $\begin{array}{l}\text { Submerged } \\
\text { wood }\end{array}$ & $\begin{array}{l}\text { Submerged } \\
\text { wood }\end{array}$ & Submerged wood & Dead wood & $\begin{array}{l}\text { Submerged } \\
\text { wood }\end{array}$ \\
\hline
\end{tabular}

2. Ascospores 3-septate $\ldots \ldots \ldots \ldots \ldots \ldots \ldots \ldots 3$

2. Ascospores 5-septate . . . . . . . . . A. hsilio

3. Ascospores longer than $30 \mu \mathrm{m} \ldots \ldots \ldots$. .... sawada

3. Ascospores less than $30 \mu \mathrm{m}$ long ....... A. palmicola

4. Ascospores with mitriform end cells, longer than $62.5 \mu \mathrm{m} \ldots \ldots \ldots \ldots \ldots \ldots$ A. mitriformis

4. Ascospores lacking mitriform end cells, shorter than $62.5 \mu \mathrm{m} \ldots \ldots \ldots \ldots \ldots \ldots \ldots$

5. Ascospores mostly 42-55 $\mu \mathrm{m}$ long ...... A. lignicola

5. Ascospores mostly 53-62 $\mu \mathrm{m}$ long ........ A. wulai

\section{ACKNOWLEDGMENTS}

We are thankful to the Hong Kong Research Grants Council and the University of Hong Kong for grants to study freshwater fungi. V. M. Ranghoo is grateful to The University of Hong Kong for the award of a Postgraduate Studentship. Professor E. B. G. Jones is thanked for his discussion on the placement of the two new fungi. W. H. Ho is thanked for his valuable suggestions and for reading the manuscript. Dr T. K. Goh is thanked for his discussions on the anamorphs and K. M. Tsui is thanked for the information on A. aquatica. A. Y. P. Lee and H. Y. M. Leung are thanked for photographic and technical assistance. S. Sivichai, H. S. Chang and Y. S. Hsieh are thanked for the information on the different taxa mentioned in the text prior to acceptance of their respective papers.

\section{LITERATURE CITED}

Barr, M. E. 1990. Prodromous to nonlichenized, pyrenomycetous members of class Hymenoascomycetes. $M y$ cotaxon 39: 43-184.

Chang, H. S., Y. S. Hsieh, E. B. G. Jones, S. J. Read, and S. T. Moss. 1998. Aquatic ascomycota: New freshwater species of Ascotaiwania and Savoryella from Taiwan. Mycol. Res. 102: 709-718.

Goh, T. K., W. H. Ho, K. D. Hyde, and T. E. Umali. 1997. New records and species of Sporoschisma and Sporoschismopsis (hyphomycetes) from wood submerged in the tropics. Mycol. Res. 101: 1295-1307.

Ho, W. H., K. D. Hyde, and I. J. Hodgkiss. 1997. Ascomycetes from tropical freshwater habitats: the genus $\mathrm{Sa}$ voryella, with two new species. Mycol. Res. 101: 803809.

Hughes, S. J., and K. A. Pirozynski. 1972. Dicoccum Corda. Canad. J. Bot. 50: 2526-2527.

Samuels, G. J., F. Candoussau, and J. F. Magni. 1997. Fungicolous pyrenomycetes 2. Ascocodinaea, gen nov., and reconsideration of Litschaueria. Mycologia 89: 156-162.

Sivanesan, A., and H. S. Chang. 1992. Ascotaiwania, a new amphisphaeriaceous ascomycete genus on wood from Taiwan. Mycol. Res. 96: 481-484.

Sivichai, S., N. J. Hywell-Jones, and E. B. G. Jones. 1998. Lignicolous freshwater ascomycete from Thailand, 1. Ascotaiwania sawada and its anamorph state Monotosporella Mycoscience 39. (In press)

Wong, S. W., K. D. Hyde, and E. B. G. Jones. 1998. Annulatascacae, a new ascomycete family from the tropics. Ascomycetum 16: 17-23. 